\title{
Joint programming for urban transformations: the making of the JPI Urban Europe Strategic Research and Innovation Agenda
}

Jonas Bylund

Correspondence: jonas.bylund@jpiurbaneurope.eu

JPI Urban Europe Management Board, c/o IQ Samhällsbyggnad, Drottninggatan 33, SE-111 51 Stockholm, Sweden

\begin{abstract}
The Joint Programming Initiative (JPI) Urban Europe, a transnational initiative by European countries in partnership with the European Union (EU) to tackle the challenge of sustainable urbanisation by programming urban research and innovation, launched its updated Strategic Research and Innovation Agenda (SRIA) in February 2019. Developed in the field of sustainable urbanisation, it is based on a wide set of sectors, disciplines, research frontiers, and their asymmetrical interconnections, as well as consultations among stakeholders in these areas, ranging from global policy and EU levels over national to regional and local actors including civil servants and politicians, researchers, commercial actors, civil society. Since the international landscape of urban policy and particularly urban transformations has recently been shifting with UN Agenda 2030, UN Habitat New Urban Agenda, and, in Europe, with an Urban Agenda for the EU, urban research and innovation, at least the parts tackling sustainable urbanisation, strives to elaborate how to support these objectives. Together with an account of how this was done from the insider perspective of a programme manager, this note presents questions and issues that will direct the JPI Urban Europe programming beyond 2020. The updated JPI Urban Europe agenda's main novelty is a dilemma-driven approach to the thematic priorities in the programming activities and a transition arena concept for its implementation.
\end{abstract}

Keywords: Urban transformations, Communities of practice, JPI urban Europe, Dilemmas, Institutional practice, Knowledge practices, Agenda, Sustainable urbanisation

\section{Policy and practice recommendations}

- The type of policy agenda discussed in this paper aims to guide and align both national and transnational research and innovation programming (funding) and policy for urban transformations.

(C) The Author(s). 2020 Open Access This article is licensed under a Creative Commons Attribution 4.0 International License, which permits use, sharing, adaptation, distribution and reproduction in any medium or format, as long as you give appropriate credit to the original author(s) and the source, provide a link to the Creative Commons licence, and indicate if changes were made. The images or other third party material in this article are included in the article's Creative Commons licence, unless indicated otherwise in a credit line to the material. If material is not included in the article's Creative Commons licence and your intended use is not permitted by statutory regulation or exceeds the permitted use, you will need to obtain permission directly from the copyright holder. To view a copy of this licence, visit http://creativecommons.org/licenses/by/4.0/. 
- To follow a dilemma-oriented approach means taking into account frictions involved in urban issues around sustainable urbanisation, i.e. the 'problem-owners' are called to define their challenges and needs.

- The dilemma-oriented approach promotes transdisciplinary research and innovation, and funding opportunities are needed to progress this move.

- Transdisciplinarity across sectoral boundaries is also well served by a transnational community of practice among researchers and other stakeholders.

- Interdisciplinary approaches in the fragmented context of urban sustainable research frontiers are important to support urban transformations.

- It is crucial to be able to operationalise the integrated urban development principles in the New Leipzig Charter to be launched 2020.

\section{The challenge to joint programming on urban concerns}

JPI Urban Europe is one of ten joint programming initiatives that was borne out of the EU. Typically, these initiatives consist of a governing decision-making body of Member States' formal delegates from ministries or national/regional expert authorities (e.g. Governing Board); an operative body to implement the decided action lines that are staffed by in-kind contributions from Member States (e.g. Management Board), at times a working group of funders, a scientific advisory function (e.g. a Scientific Advisory Board), and usually a more general stakeholder advisory body (e.g. Stakeholder Involvement Platform); cf. Figure 1 for the JPI Urban Europe formal organigram . The JPIs are one type of response in the research and innovation funding landscape to the question on how to tackle the great societal challenges of our times as well as help member states coordinate their efforts and investments in these areas so as not to re-invent the wheel. For an international comparison, it is similar to the Belmont Forum although with the added dimension of the EU partnership. Hence, the programme high level support is run directly by the member states themselves, ${ }^{1}$ with EC as observer and with strong synergy to EC policy on the urban dimension in framework programme budgets as well as European Regional Development Fund programmes such as URBACT and Urban Innovation Actions. ${ }^{2}$ The member states are represented by ministries and funding authorities, which work together on calls of various kinds and in exchange of results. Policy-science communication and cooperation are key activities. As is promoting transdisciplinary approaches, meaning co-creation of knowledge and matter between academic research and actors beyond (sometimes simplified as a quadruple helix of collaboration between academic research, policy, business, and civil society (cf. McAdams and Debackere 2018)) to support urban transition pathways. The specific societal

\footnotetext{
${ }^{1}$ The initiative was formally launched in 2011 by the European Council. However, it works in various types of partnerships with the EU but is governed directly by the member states themselves. Hence, member states in JPI Urban Europe are not necessarily members in the EU. Particularly when it comes to calls and the Funding Agency Working Group, any national or regional funder is welcome to join. For more information, please visit $>$ https://jpiurbaneurope.eu<. States currently involved in the various actions: Norway (Chair), Austria (Vice Chair), Italy (Vice Chair), Belgium, Cyprus, Denmark, Estonia, Finland, Germany, Latvia, Lithuania, The Netherlands, Slovenia, Sweden, United Kingdom (Non-EU), Poland, Portugal, Romania, Spain, Turkey (Non-EU).

${ }^{2}$ For more information, please see European Regional Development Fund (ERDF) $<$ https://ec.europa.eu/ regional_policy/en/funding/erdf/ >; URBACT < https://urbact.eu/ >; Urban Innovation Actions < https:// www.uia-initiative.eu/en $>$.
} 


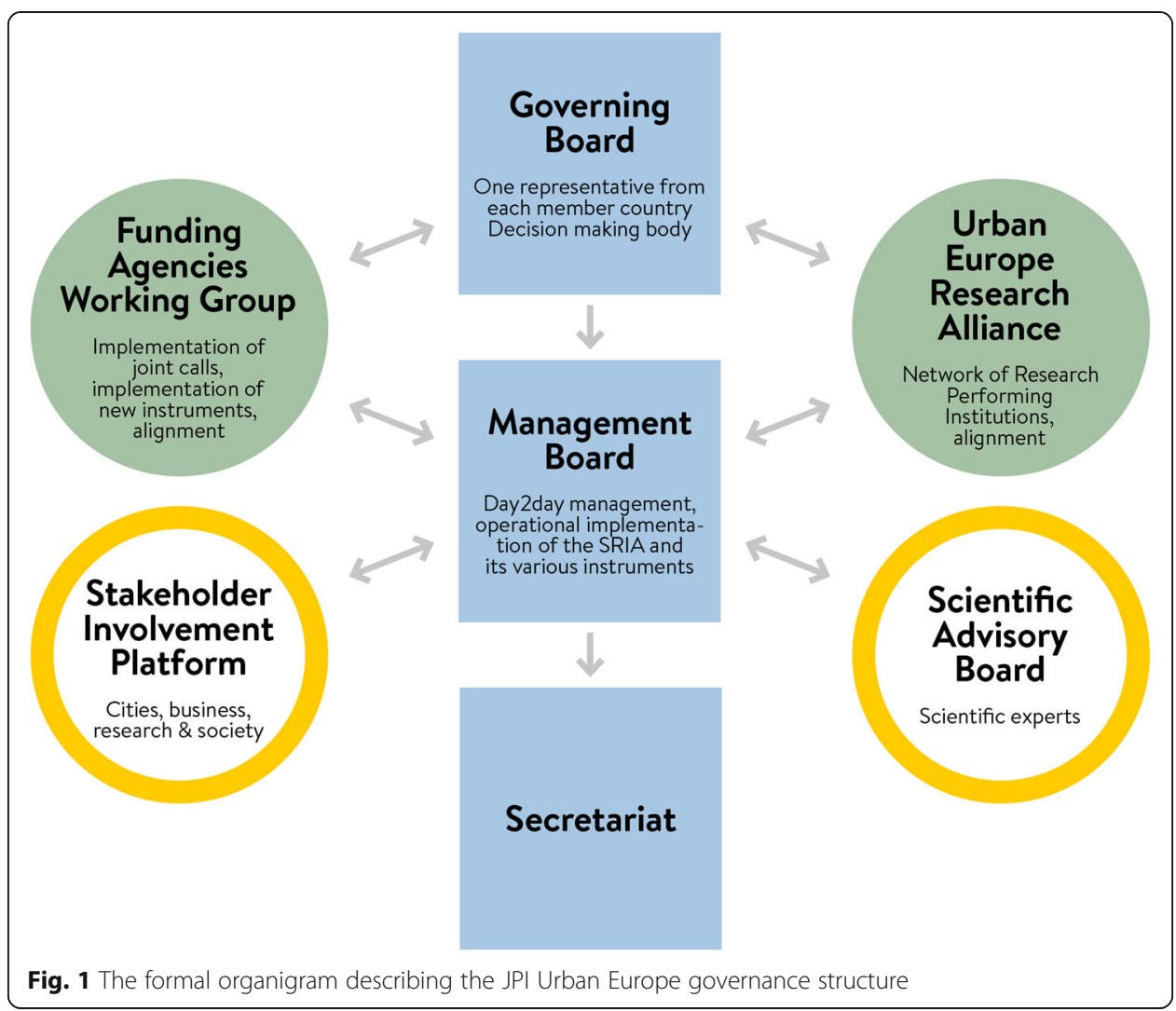

challenge is how to make cities and urban areas sustainable and to approach this in an integrated way (cf. 2007; 2020).

The Joint Programming Initiative (JPI) Urban Europe recently updated its updated Strategic Research and Innovation Agenda (SRIA) (JPI Urban Europe 2015, 2019). This updated agenda is set to stake out the directions of its urban research and innovation programming beyond 2020. Typically this type of agenda serves at least three related purposes: 1) to present the general outline and frame what topics and themes to be called for in programming; 2) in transnational or transorganisational joint programming, to have organisations, governments and/or funding agencies aligned in this; 3) to signal and align with other transorganisational, transnational and international programming initiatives and policy actors (e.g. in the case of JPI Urban Europe with the European Commission (EC), Belmont Forum, JPI Climate) in order to enable complementarities and synergies rather than double work and parallelism. As the paper will focus on the drafting process and how it has also shaped the composition and thematic direction of the agenda, at this point it is enough to state why the relatively hasty update was required. By the time the first agenda was launched, an iteration and update was quickly foreseen since at least three important sets of international policy related to sustainable urbanisation were taken in 2015-2016 that the programming should relate to: UN Agenda 2030 (UN 2015b), The Paris Agreement (UN 2015a), and the Urban Agenda for the EU (EC 2016). Of course, since they were in the pipeline, they had an implicit bearing on SRIA 2015. However, the update was not just about being able to reference the published policy texts but rather to gauge by what and how they were re-shaped entering the congestion of the real (to paraphrase Hägerstrand 1986). 


\section{Co-creative transnational agenda setting}

Now, the name of the programme may imply it is a strictly European affair - why should the international community around the Urban Transformations Journal care? The fact that JPI Urban Europe collaborates with the Belmont Forum, that it develops bilateral calls with China, and Latin American and 'South' countries express interest in joining the regular call activity (see Fig. 2), has made JPI Urban Europe certain that the concerns around the dilemmas and issues outlined in the updated agenda are not restricted to the European setting. In a sense, the research and innovation programming agenda is a knowledge diplomacy mechanism within and beyond Europe since it is used as an intermediary to search out and shape common goals and directions to move urban research innovation in joint undertakings.

During the last 8 years, JPI Urban Europe has moved its programming beyond being a mere 'call machine' to support at the same time a transnational innovation ecosystem or network of urban transition activities and approaches as well as local urban settings with their transitioning. On the one hand, this stems from the fact that JPI Urban Europe (as with all the JPIs) is a new instrument and its programming is explorative, not to say innovative, in its own right in the context of research and innovation funding. That is, while calling for challenge-driven research and innovation with a strong emphasis on transdisciplinary co-creative approaches in local urban settings, JPI Urban Europe itself has had to figure out how to have funding agencies work together and trust each other, how to partner with the EC, how to make the various events by and in collaboration with JPI Urban Europe more knowledge generating and active learning for all involved rather than simply a long row of statements and presentations. On the other hand, the European Commission itself - to address the research and innovation needs in urban sustainability transitions - requires the network organisation to be reflexive beyond call technicalities, at the very least since the field of urban research and innovation is very diverse and fragmented in clusters of various disciplinary and sectoral foci. It may not always be obvious to actors outside these inner workings, but there is a sense that those of us who work with programming aspects (e.g. strategic relations, thematic content, communication and stakeholder involvement) also have to learn and 'be the change you want to see' as much as possible.

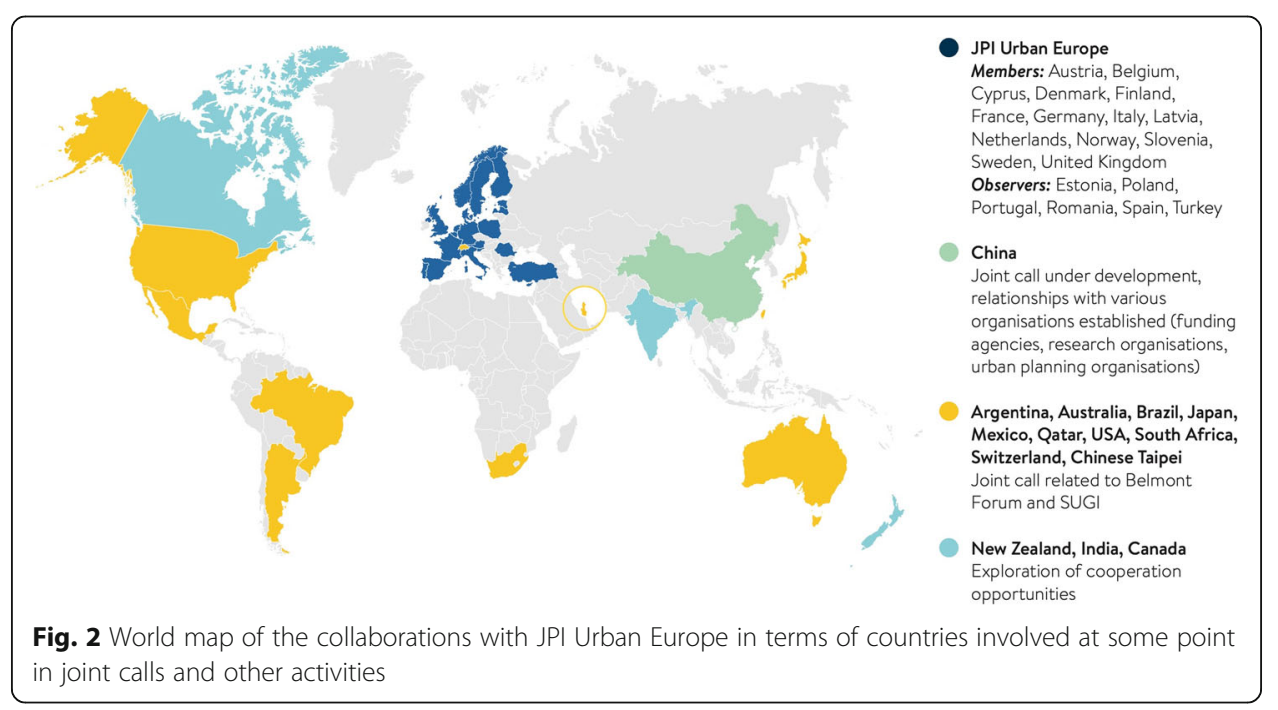


The JPI Urban Europe focus is on various transition pathways to push for urban transformations overall without using a one-size-fits-all approach. By transition pathways and urban transformations, which are at times seemingly used synonymously in policy communications, JPI Urban Europe relies mainly on the distinction made by Hölscher et al. (2018: 2), i.e. they are not mutually exclusive but do refer to different scopes and systemic perspectives: transitions concern 'the processes and dynamics producing patterns of change' in societal sub-systems while transformations denote a more overarching view on larger scale changes in societies and efforts to understand them 'from emergent patterns of change' and their 'outcomes at a systemic level.' JPI Urban Europe harbours a project portfolio directed towards shaping a critical mass in knowledge provision to urban transition pathways with the ultimate aim to support urban transformations (cf. Kabisch et al. 2019). However, as the portfolio grows, this also requires more and innovative strategic syntheses both in terms of results and in terms of how to understand the challenges for stakeholders.

The SRIA update may seem a bit early. After all, the previous SRIA ran for 2020 and still had a lot to give, so to speak, when it comes to urban transition pathways and thematic priorities. Nevertheless, the SRIA 2.0 update was foreseen almost from the launch of SRIA 2015. A relatively speedy recommencement of the scoping work was intended and started already in 2016. It was foreseen since the UN Agenda 2030 and the SDGs were in the pipeline and launched shortly after, the Paris Agreement on Climate Action (COP 21), the UN-HABITAT 'New Urban Agenda' were also published, and the work to shape/implement the Urban Agenda for the EU (UAEU; which is the first general and joint urban policy in the history of this region!) was commenced. A couple of rather important international policy documents in terms of giving policy a direction and articulating the general challenges and priorities concerning sustainable development and urban futures. The update was hence needed to specify how JPI Urban Europe should respond and support the achievement of the aims set out in these policies regarding sustainable urbanisation. Furthermore, JPI Urban Europe also quickly realised that SRIA 2015 did not adequately address the issue of the contemporary fragmented landscape of urban research and innovation and policy (cf. De Jong et al. 2015) that required some reflection by an urban symposia series since it is a key issue in terms of understanding and supporting the variegated urban transition pathways to move towards urban transformations.

\section{How JPI Urban Europe developed the SRIA 2.0}

JPI Urban Europe launched its updated SRIA in February 2019 (JPI Urban Europe 2019). It was preceded by hectic work reflecting on the messy urban development dynamics in practice and on a wide set of consultations, ranging from global and EU level stakeholders over national and regional, to local, researcher, commercial, civil society stakeholder groups. The following is reconstruction of the SRIA development along a timeline (see Fig. 2) that, even if historical and not a prescribed procedural regulation on drafting, more or less reflects the standard of the kinds of turns this type of programme development takes in JPI Urban Europe.

Although, who were the movers? Primarily the Management Board, which was tasked to draft the update for the Governing Board. In 2017 the Governing Board had just 
developed a long-term strategy in more funding policy technical terms on the JPI Urban Europe vision, main achievements, and future goals concerning the societal challenge of sustainable urbanisation for 2020-2026 (JPI Urban Europe: Vision, main achievements and future goals 2020-2026, Unpublished). This document served as a backbone to the agenda update. The main direction in how to support this in all its complexity is that JPI Urban Europe has the ambition to:

... become a well-recognised source of knowledge for informing European and international urban policies. The next development phase of JPI UE thus has to focus on activities that respond to real urban needs and strengthen the implementation of research results. To better meet societal and cities' needs, JPI UE in all its activities will strive to mobilise urban stakeholders, to co-create ideas and solutions and support mutual learning. For realising urban transitions and enhancing impact of the investments, JPI UE needs to contribute to capacity building in urban planning, management, (regional, national, EU, and international) policy making and society at large. (JPI Urban Europe 2017: 3-4)

Unfortunately for this paper, there was not much drama involved in the drafting of the agenda update. It was of course exciting for us who were in the middle of steering and exploring the European landscape of issues and actors on all levels. But the below may read more as a list of stops on a highway trip. Although it was not a particularly rationalist planning process either. In a way, this resembles the classic argument in planning studies on that much of planning is neither very conflictive nor rational but more similar to the 'muddling through' in 'successive limited comparisons' (cf. Lindblom 1959).

However, the formal timeline for the SRIA 2.0 development starts with commissioning a task to the Scientific Advisory Board (SAB; see Fig. 3). This task consists in shaping a position paper with recommendations around issues such as: what does the international policies related to sustainable urbanisation entail and how do they affect urban research and innovation? How could JPI Urban Europe contribute with research and innovation in the best possible way? SAB started drafting a position paper on the scientific warrants of an updated agenda (published as Kabisch et al. 2019) mainly by aiming to support the UN Agenda 2030 SDG 11 implementation.

Next, the Management Board asked the Urban Europe Research Alliance (UERA) for recommendations and advice on what themes and issues the agenda should address. The UERA is driven by research institutions and organisations across Europe. Their input was detailed and thorough.

These first two steps would then characterise the first phase of the agenda development as a scoping exercise by scientific and research actors. However, at the same time, the Management Board opened up an interface for public and stakeholder input as a general and open web-based consultation. The input ranged from high and low, conceptual abstractions to simple concrete concerns and recommendations. There were researchers, NGOs, but also interest organisations in and around Brussels such as Eurocities, and global ones such as ICLEI. This openness was risky, since the operative principle ofthe Management Board holds it important to make sure all input is 


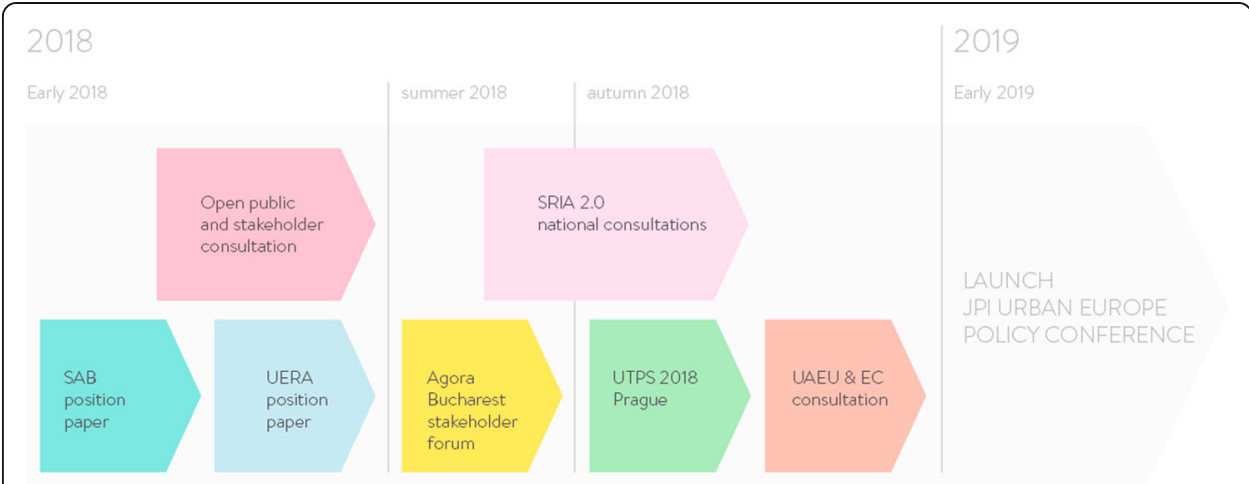

Fig. 3 Timeline of the SRIA 2.0 formal development phases. It depicts two degrees of openness: the upper level arrows represent external, open, and wide consultations, the lower level arrows represent consultations with organisations and events that, although not hermetically sealed off, required membership or 'being in the loop' in various ways

somehow reflected, even if not all of it may be recognised as taken into account from any specific actors' point of view.

In the second phase, this horizontal co-creation approach was taken a step further as the processing of the public consultation, after a slight 'calibrating' or 'rough mix' (as music sound engineers put it) by the Management Board, took place at an AGORA Forum event in Bucharest, April 2018. This became a key milestone. About 80-100 participants, mainly researchers, but also stakeholders from other categories such as business, policy-makers, civil society, from all over Europe. Future Earth, ministries, researchers from projects funded by JPI Urban Europe. For 2 days, this entailed working with professional facilitation to braid, quilt, and work the material through stakeholder exchange and dialogues, back and forth, to shape issue areas. Through successive iterations on questions and then sets of questions and concerns, revisioning, rephrasing, the large stakeholder group sorted out the most pressing issues (Fig. 4).

From the AGORA Forum discussions in Bucharest and the output generated, the Management Board distilled the results from it, five thematic areas and some implementation issues. After an outline write-up, it was time to report and query the Governing Board on directions. This resulted in 'ok, go!' for a consultation along the lines of national communities and stakeholders, i.e. the National Contact Points in JPI Urban Europe would bring the 'memo' to its urban research and innovation community and ask them for comments, ideas, input, etc.

Then the European Commission (EC), which has an 'interservice' group on urban matters across its departments (Directorate General) as well as the Joint Research Centre (JRC) were consulted. As a further and crucial alignment of the agenda, the question also went out to the Urban Agenda for the EU Partnerships (UAEU) for their view on the agenda update. These partnerships consist mainly of city authority representatives, although not excluding civil society, business, and research actors.

The outline and 'prototype' were at the same time refined and reflected upon by academic research in an Urban Transitions Pathways Symposium (UTPS) in the fall 2018. During discussions and workshops with the material, it became clear the Management Board had to scrap one of the themes and integrate some of the core concerns in the remaining four. This concerned the theme outlining a friction between liveability and 


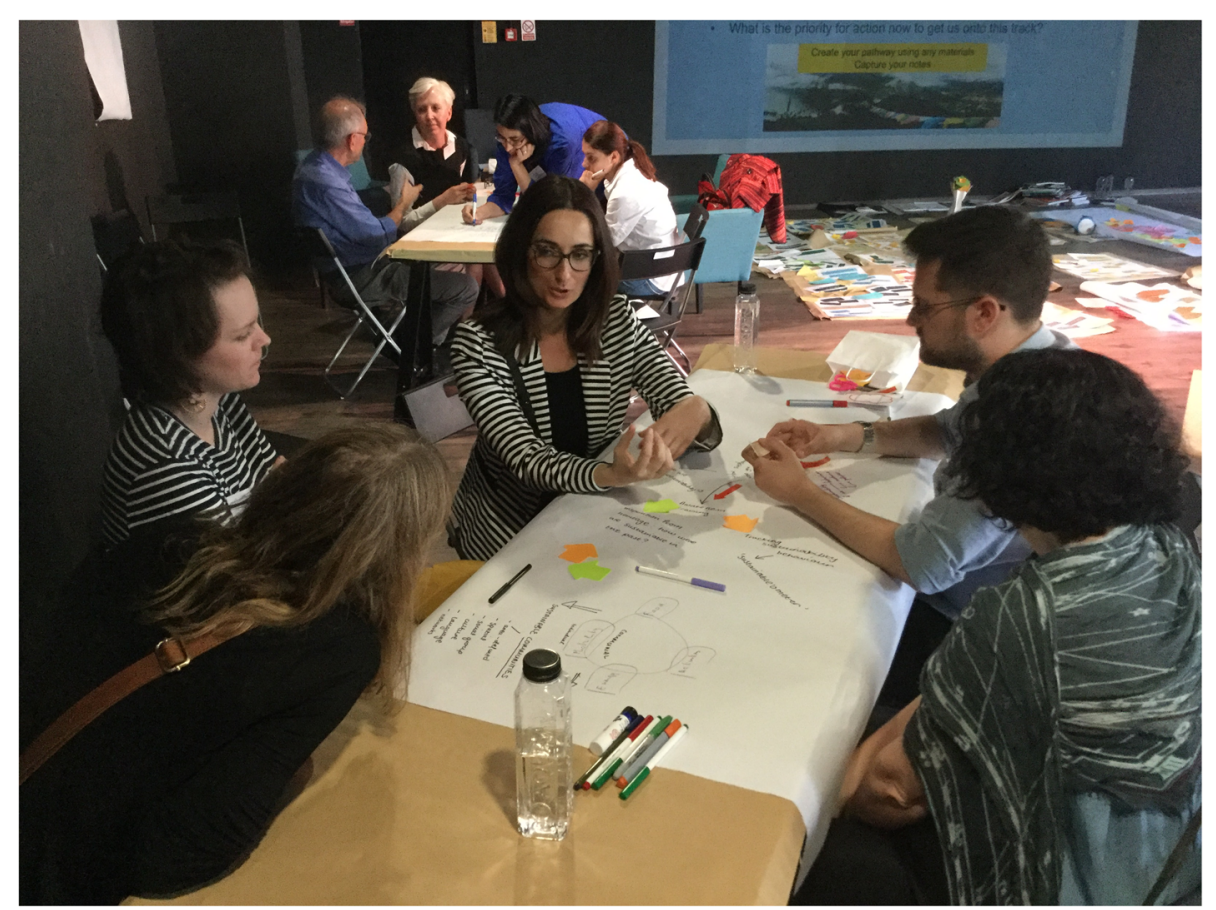

Fig. 4 The AGORA Forum, Bucharest April 2019, where issues, concerns, challenges were iterated, hybridised, and re-combined into dilemmas for sustainable urbanisation. Photo: Christine Bell, Centre For Facilitation

(technical) functionality. It became obvious that it required too much conceptual support to make the point (in the sense that the statements generally required quite a lot of academic contextualisation in order to travel across stakeholder groups) that was heard throughout the online consultation and in the AGORA.

Finally, there are four main themes in the SRIA 2.0 update: 1) Digital transitions in urban governance; 2) From resilience to urban robustness; 3) Urban infrastructures; 4) Inclusive public spaces. These themes are understood as dilemmas, that is as wicked issues that appear in-between actors. ${ }^{3}$ Dilemmas are hence boundary objects that serve as communication interfaces for a wider range of stakeholders and affected publics, groups, etc. Hence, the dilemma-driven approach is a way to work towards four prioritised future orientations for urban transformation research, e.g. as identified by Wolfram et al. (2016: 23-24). To tackle dilemmas we need radical innovation, or perhaps rather that approach of tackling dilemmas will generate radical (systemic) innovation that allows addressing the complexities and cross-cutting issues that characterise urban transformations.

The time for drafting was tight and the SRIA 2.0 was launched in Brussels already in February 2019 at a high-level policy conference. The development had been done with the sense to increase opportunities for input by various types of stakeholders, from EC to small social innovation actors on a neighbourhood level. For us who will use it as an instrument to guide programming but also to communicate concerns for the wider

${ }^{3}$ Wicked issues is the 'positive' policy jargon for what in planning studies is termed 'wicked problems' after the classic paper by Rittel and Webber (1973) and elaborated as 'super wicked problems' in the Urban-Nexus (2014) project findings around integrated urban governance. 
policy community in Europe and internationally to mobilise around, one of the positive outcomes from this ambition is that we still register different voices (such as network organisations or policy actors) that reflect the complexities involved in urban transformations. Particularly the dilemma-driven approach that developed out of the process seems to make a difference in this policy community, in that it presents more of the frictions involved, which is recognised to reflect a higher degree of 'truthfulness' in representing the messy practical circumstances and wicked issues on the ground.

It is for these reasons that the SRIA 2.0 develops a dilemma-driven approach and, in retrospect, suggests a transition arena framework (Loorbach 2010) to implement the programming and support urban transformations. The transnational transition arena is a way to understand or perform an urban innovation ecosystem that works beyond national boundaries. It is an ongoing constructive approach that has been underway the last 10 years. Broadly speaking it is to 'connect the dots' in the dense and diverse network of urban transition research and initiatives characterised above but also to support capacity building in the intentional absence of a 'new paradigm'. Connecting the dots is a strategic principle and transition arena hypothesis in JPI Urban Europe that holds the wish to increase and shape better communication in-between the various clusters of research fields, sectors, and silos that currently work in paralleland that tend to fragment the field of urban transformations by having different epistemological practices, ontological understandings, and (academic) capital interests to hinder the effective workings of a single paradigm (cf. Bylund 2017).

\section{Conclusions: surfing in the archipelago of urban research and innovation}

The central concern in the SRIA 2.0 is not really its thematic priorities. Rather, it is the dilemma-driven approach itself and how to programme in support of urban transitions and transformation when the landscape of relevant activities in terms of themes, disciplines, and approaches is fragmented. This landscape looks more like an archipelago a group of islands operating independently, rather than an integrated system of action that generates a concerted effort to promote urban sustainability. From the Urban Transitions Pathways Symposia, we learned that it is probably not a good idea to set up yet another paradigm, yet another concept to capture it all, since both policy and research in Europe recognize:

... research on cities and systemic change for sustainability involves terminological variety, epistemological disjunctions and blind spots that lack both recognition and reflection in order to inform future strategies. (Wolfram et al. 2016:18)

Furthermore, as 'a plethora of new city categories has entered the policy discourse' (De Jong et al. 2015: 26), i.e. urban future narratives that generate very different urban development dynamics, partly also pursuing conflicting goals, any overarching paradigm seems impractical and may even be detrimental to the various transition pathways they drive.

Hence, there are several reasons why the SRIA 2.0 dilemma-driven approach is an important undertaking in this context.

Firstly, to progress transdisciplinarity, of course there need to be corresponding funding opportunities for research to co-create knowledge and activities with other types of 
stakeholders. These have been more in the nooks and crannies among programmes and calls for academic research. At least in Europe. Apart from the larger and, well, quite complicated types of calls in the research and innovation framework Horizon 2020 of the European Commission (and its successor framework Horizon Europe to be implemented 2021-2027), there are few transnational and perhaps also few national opportunities for truly transdisciplinary consortia. Even while academics at times may fear having to share scarce funding resources with yet more and very different types of actors, this logic according to which only academic research is fundable may lead back to linear and Fordist kind of conveyor belt approaches to scientific knowledge production. There is a need for a 'cybernetic feedback loop' of building excellence to be able to raise the stakes among funders and review panels on transdisciplinary co-creative approaches.

Secondly, it is important to build a transnational community of practice. Or communities of practices in the urban transformation archipelago. There is an urgent need, not only among scholars, for some new connections between various island clusters. This is not a linear causality context, where simply more funding will beget new solutions that in turn would save our planet. Rather, looking at JPI Urban Europe's role as an intermediary in supporting urban transformative capacities (cf. Wolfram 2018), it is clear that we also need to work in some ways with the incentives on the demand side, so to speak. Apart from fostering transdisciplinary practices and consortia, there is also the need to build collaborative 'infra-notions' and infrastructures and support communities of practice and capacity for sustainable urban transformation in a wider sense (an argument can be made that 'transdisciplinary' is academic jargon reflecting a perspective from the Ivory Tower, but it carries less meaning outside the academic world).

More importantly, it is not only research that gains from transnational collaboration. Of course, urban research and innovation is already in many instances fully international in its debates and aims, depending on what issues and frontiers one looks at. But city administrations and public officials therein, business as well as civil society actors - those many times labelled 'practitioners' (as if 'theory' was not a kind of knowledge practice?) - in urban development also signal interest in learning across borders. And not just within policy silos and academic disciplinary boundaries (cf. CMSP 2007; CMSP 2020; BBSR 2018).

Thirdly, there is still a need to foster interdisciplinarity. Given the fragmented research landscape in urban studies, urban ecology, planning studies, and so on, there is a high risk of more conventional disciplinary approaches to reinvent the wheel. Although one might criticise and rebel against an academic knowledge production in which excellence is only indicated by self-referential academic standards and bibliometrics (cf. Durose et al. 2018), it is a current mainstream setting, an institutional framework we need to work with at the moment striving to cultivate ecosystems that may move us into hopefully more productive and transformative collaborations.

For these reasons, JPI Urban Europe is also delighted to be involved in the shaping of the Urban Transformations journal and support its aims. From the point of view of the everyday work of transnational programming support for research and innovation on sustainable urbanisation, the journal is important because of the potential synergies to JPI Urban Europe. That is, not just because of providing a channel or an outlet for 
transdisciplinary co-creative transformation practices among urban researchers, but because of the nature of the work that the strategic programming entails in terms of finding and promoting robust knowledge.

From this point of view, then, Urban Transformations is a timely intervention in the publishing landscape. Regarding learning across borders, this means that Urban Transformations is well positioned to, while promoting rigorous academic research, serve as a boundary spanner in a similar sense as how the SRIA 2.0 and JPI Urban Europe efforts strive to connect and shape conceptual infrastructures in-between the fragmented frontiers, issues, concerns, and urban imaginaries in the current urban research and innovation landscape.

\section{Abbreviations}

EC: European Commission; E.G.: Exempli gratia; JPI Urban Europe: Joint Programming Initiative Urban Europe; SRIA: Strategic Research and Innovation Agenda; SDG: (UN Agenda 2030) Sustainable Development Goals;

UAEU: Urban Agenda for the European Union; UN HABITAT: United Nations Human Settlements Programme

\section{Acknowledgements}

Jonas Bylund is very grateful to editor and reviewer comments.

\section{Author's contributions}

Jonas Bylund carried out the drafting of the intervention. The author(s) read and approved the final manuscript.

\section{Authors' information}

Jonas Bylund is part of the JPI Urban Europe Management Board since 2013. His main responsibility is science-policy communication and to develop urban research and innovation funding calls with affiliated funding agencies as well as other initiatives. Since 2013 he is also employed at IQS, the Swedish Centre for Innovation and Quality in the Built Environment. He is trained in human geography and social anthropology, with a specific research focus on the knowledge practices in planning and environmental sciences. His PhD thesis Planning, Projects, Practice (2006) investigated a local investment programme concerning new environmental technologies in Stockholm urban development and was an attempt to translate actor-network theory into planning studies. He is an experienced lecturer in urban and regional planning, with a particular focus on epistemology and ontology in the social sciences. He is also a consultant with Urbanalys.

\section{Funding}

Not applicable.

\section{Availability of data and materials}

Data sharing not applicable to this article as no datasets were generated or analysed during the current study.

\section{Consent for publication}

Permission to photograph the participants was obtained at the event by CFF from the participants.

\section{Competing interests}

The author declare that they have no competing interests.

Received: 21 February 2019 Accepted: 22 June 2020

Published online: 04 September 2020

\section{References}

BBSR. 'Ten years after the Leipzig charter: the enduring relevance of integrated urban development in Europe', Federal Institute for Research on building, Urban Affairs and spatial development, <https://agendastad.nl/wp-con-tent/uploads/2 017/08/Ten-years-after-the-Leipzig-Charter-low-res.pdf>. Bonn: BBSR; 2018.

Bylund J. Connecting the dots by obstacles? Friction and traction ahead for the SRIA urban transition pathways, UTPS 2016 outcomes and booklet intro. Retrieved from https://jpi-urbaneurope.eu/app/uploads/2017/04/Bylund_Connecting_the_ dots-utps2016_booklet_intro-201704.pdf. Wien: JPI Urban Europe; 2017.

CMSP. (2007). Leipzig charter on sustainable European cities. Final draft 2 May 2007, EU2007.DE, Retrieved from https://ec. europa.eu/regional_policy/archive/themes/urban/leipzig_charter.pdf. Accessed 2018-10-15, Informal Council of European Ministers responsible for spatial planning.

CMSP (2020). The new Leipzig charter: the transformative power of cities for the common good. Unpublished draft 2020-0505 informal Council of European Ministers responsible for spatial planning.

De Jong M, Joss S, Schraven D, Zhan C, Weijnen M. Sustainable-smart-resilient-low-carbon-eco-knowledge cities; making sense of a multitude of concepts promoting sustainable urbanization. J Clean Prod. 2015;109:25-38.

Durose C, Richardson L, Perry B. Craft metrics to value co-production. Nature. 2018;562:33.

EC. (2016). Urban agenda for the EU: pact of Amsterdam. Retrieved from https://ec.europa.eu/futurium/en/content/pactamsterdam.

Hägerstrand, T. Den Geografiska Traditionens Kärnområde. Svensk Geografisk Årsbok 1986;62:38-43. 
Hölscher K, Wittmayer JM, Loorbach D. Transitions versus transformation: what's the difference? Environ Innov Soc Transit. 2018;27:1-3.

JPI Urban Europe. Strategic research and innovation agenda: transition towards sustainable and liveable urban futures. Retrieved from http://jpi-urbaneurope.eu/app/uploads/2016/09/JPI-UE-Strategic-Research-and-Innovation-Agenda-SRIA. pdf. Accessed 201830 Nov. Wien: JPI Urban Europe; 2015.

JPI Urban Europe. Strategic research and innovation agenda 2.0. Retrieved from https://jpi-urbaneurope.eu/app/uploads/201 9/02/SRIA2.0.pdf. Accessed 2019-02-12. Wien: JPI Urban Europe; 2019.

Kabisch S, Finnveden G, Kratochvil P, Sendi R, Smagacz-Poziemska M, Matos R, Bylund J. New urban transitions towards sustainbility: addressing SDG challenges (research and implementation tasks and topics from the perspective of the scientific advisory board (SAB) of the joint programming initiative (JPI) Urban Europe). Sustainability. 2019;11(8):2242.

Lindblom CE. The science of 'muddling through'. Public Adm Rev. 1959;19(2):79-88.

Loorbach D. Transition Management for Sustainable Development: A Prescriptive, Complexity-Based Governance Framework. Governance. 2010;23(1):161-183.

McAdam M, Debackere K. Beyond 'triple helix' toward 'quadruple helix' models in regional innovation systems: implications for theory and practice. R\&D Manag. 2018;48(1):3-6.

Rittel HWJ, Webber MM. Dilemmas in a general theory of planning. Policy Sci. 1973;4:155-69.

UN (2015a). The Paris agreement. United Nations framework convention for climate change. Retrieved from https://unfccc. int/process-and-meetings/the-paris-agreement/the-paris-agreement.

UN (2015b). Transforming our world: The 2030 agenda for sustainable development. Retrieved from https:/ sustainabledevelopment.un.org/post2015/transformingourworld.

Urban-Nexus (2014). Engaging society for a sustainable city: URBAN NEXUS research findings, URBAN-NEXUS FP7 project no. 282679, Retrieved from https://cordis.europa.eu/docs/results/282/282679/final1-results-urban-nexus.pdf.

Wolfram M. Learning urban energy governance for system innovation: an assessment of transformative capacity development in three South Korean cities. J Environ Policy Plan. 2018;21(1):30-45.

Wolfram M, Frantzeskaki N, Maschmeyer S. Cities, systems and sustainability: status and perspectives of research on urban transformations. Curr Opin Environ Sustain. 2016;22:18-25.

\section{Publisher's Note}

Springer Nature remains neutral with regard to jurisdictional claims in published maps and institutional affiliations.

Ready to submit your research? Choose BMC and benefit from:

- fast, convenient online submission

- thorough peer review by experienced researchers in your field

- rapid publication on acceptance

- support for research data, including large and complex data types

- gold Open Access which fosters wider collaboration and increased citations

- maximum visibility for your research: over $100 \mathrm{M}$ website views per year

At $\mathrm{BMC}$, research is always in progress.

Learn more biomedcentral.com/submissions 